\title{
Cultural sexism is ordinary: writing and re-writing women in academia
}

\author{
Heather Savigny \\ Professor of Media Discourse \\ Leicester Media School \\ De Montfort University \\ heather.savigny@dmu.ac.uk
}

Accepted and forthcoming in Gender, Work \& Organisation

\section{An academic history of one's own (with apologies to Virginia Woolf)}

But, you may say, we asked you to speak about women and writing. What does that have to do with academia? Let me explain.... As I look back, I see the way in which women's contributions to the academy have been marginalised and written out. The canons and great 'histories of thought' have as their focus the great 'dead white men' and through this construction their thinking is given greater import; their thinking has shaped the past Western world; he who controls the past controls the future? (cf. Orwell, 1987) But, l ask, where are the women? And they are there. At first I was Sophia Jex-Blake and I wanted to study medicine. I was subject to provocation and harassment and although enrolled in University, staff refused to teach me. I engaged in a legal battle in 1873 which resulted in a lords ruling women be excluded from higher education (Kennedy, 1995). By the end of the 19th century some Universities (Sheffield, Birmingham, Liverpool and Manchester) had supported my learning (as a woman), although Oxford did not follow suit until 1920, and I could not gain full membership of Cambridge until 1948 (Kennedy, 1995). I had thought that discrimination would be a thing of the past. My fore-sisters fought for my emancipation, liberation and or my equality, and my rightful place has been restored to history books (for example see Woolf, 1928/2008; Spender, 1982.) Sisterhood has been powerful (cf. Morgan, 1970). And my sisters and I have advanced into the halls of the academe in larger numbers. This success, however, renders visible a different problem: Despite years of equal opportunities legislation, I am still underpaid, discriminated against and lack representation in senior positions (Shen, 2013). The university constitutes a site of feminist struggle (cf. Bannerji et al, 1991). My current experience of academia highlights my 'performativity' (cf. Butler, 1999) within a regulatory regime whereby cultures and structures of sexism become ubiquitous and cultural sexism has become 'ordinary'. This ordinariness, however, provides me and all of my colleagues 
(irrespective of gender or sex) who are unhappy with this positioning, opportunities to embrace a performativity of change.

The fictional account above, reminds us that the history of women in Universities is one which has taken place not in a natural setting, but against backdrop of masculinist discourses which have written and defined structures, cultures and the position of women in the academy. In UK academia women make up $14.2 \%$ of University Vice Chancellors (Counting Women In, 2013: 35). According to statistics published by HESA (2012), women gain $57 \%$ of undergraduate degrees and $60 \%$ of Masters degrees. In 2011 , while $44.5 \%$ of academic staff were female, at professorial level, only $20.5 \%$ of academic staff were women (HESA, 2011). In Europe only 18\% of full professors are women (Vernos, 2013). This under representation of women at senior level invites further reflection. Why are women so under represented (and men so over represented [cf. Murray, 2012]) in senior positions? These statistics, I suggest, are symptomatic of underlying power structures which privilege hegemonic masculinity. These are manifest through hegemonic masculinised discourses in male dominated organizations which privilege and value more highly, men and masculinity (van den Brink \& Stobbe, 2009, p454).

Writing is an activity that we undertake as academics, it is something essential to our profession. As a craft we may reflect on its purpose: if we are trying to communicate our ideas writing with clarity (and/or style) is essential (Grey \& Sinclair, 2006; Sword, 2012). But writing is not always neutral and can be something which serves to exclude, marginalize or alienate (cf. Grey \& Sinclair, 2006). Spender (1980) demonstrates the way in which 
language is gendered to privilege the male; transcribe this into the written word and this gives a material form to male dominance; the material expression of dominant masculine power structures (see also Pullen 2006). While the writing of female authors may be constrained by masculine discourses, where writing may both describe and regulate (Höpfl, 2000), feminine writing can also be 'dirty', a means to challenge and 'disrupt phallogocentric discourses' (Pullen \& Rhodes, 2008: 242). Writing can also function methodologically: as a mechanism to reflect on the subjectivity of our role in the research process (Rhodes \& Brown, 2005). This article seeks to explore the ways in which women are written in to discourses and cultural praxis in the academy. I use writing, through biography, as a way to describe and expose women's experiences. In autobiography, I also reflect on my subjective relationship with the research, with the intention of engaging in feminine re-writing (cf. Pullen, 2006). From this position, I also argue that feminine and feminist writing and rewriting can form a site of resistance, where dominant discourses can be challenged and rewritten.

Feminine writing, therefore, can be both a performative and a political act (in its challenging of dominant power structures). Writing can give expression to previously unheard voices; it can constitute discursive knowledge and power regimes within which gender is 'done' or performed within the academy. Through praxis feminine writing can provide a mechanism to challenge and disrupt dominant masculinist norms and values: it provides a space whereby alternate discourses may be considered possible; gendered contemporary practices and power structures 're-written'. As such, the main argument being advanced is that just as writing plays a central role in defining the way in which gendered is 'performed', 'done' or experienced in academia so feminine writing may play a 
role in disrupting and re-writing masculinist cultural 'norms'. In what follows below, I begin with a brief discussion of the literature and positioning of women in academia. I reflect on the biographical experiences of academic women through the lens of 'cultural sexism'. I suggest that this raises the question, if sexism has become a cultural 'norm' how then can we challenge cultural sexism so that it becomes extra-ordinary, rather than ordinary? As my epistemology is located in a critical field, this requires us to think, not only what is the case, but what can we do about it? In the latter part of the article I therefore briefly reflect on feminine re-writing of institutional structures and cultures; I write to challenge the idea that cultural sexism is ordinary, and briefly discuss how the performativity of gender may be contested within academia. As such the article is structured around three broad themes: writing to understand; writing to expose; writing to challenge and change.

\section{Women and gender}

Clearly, women and gender are not synonymous. The focus below is on the gendered way in which women experience and perform gender through the writing of masculinist discourses within the academyi. I begin from the premise that gender is not only socially and discursively constructed, but it is a central part of organisational practice (Acker, 1990; Gheradi, 1994; van den Brink \& Benschop, 2012). Underlying this is a recognition that gender is something that is performed, (Butler, 1999/1990) or 'done' (West and Zimmerman, 1987) and negotiated, contested, renegotiated and re-enacted in organisations through local and collective practices (Acker, 2006; Connell, 2009; West \& Zimmerman, 1987). This renegotiation and reconstruction reinforces the idea that gender is a process (Beckwith, 1997) and once gender is understood as process rather than inherently fixed it is then possible to disrupt and to challenge dominant norms. To 'undo' gender inequality 
(van den Brink \& Benschop, 2012, p72-3) I begin with a woman centeredii approach, not to position women as the cause or source of their own under-representation, but rather to highlight the ways in which they are positioned by cultural norms and structures.

\section{Writing to understand: Writing the position of women in academia}

Adrienne Rich's work points to the absence of women as role models in Universities. She sees this, perhaps, in psychoanalytic terms where

The university is likewise a replica of the patriarchal family. The male teacher may have a genuinely 'fatherly' relation to his gifted student-daughter, and many intellectual women have been encouraged and trained by their gifted fathers, or gifted male teachers. But is the absence of the brilliant and creative mother, or woman teacher, that is finally of more significance than the presence of the brilliant and creative male (1979/1986: 139)

For Rich this descriptive absence of women has profound consequences for the social norms which may develop here. This writes a discourse that women are less likely to achieve in the academy; brilliance and creativity are thus represented as male characteristics, properties of the masculine and in male dominated contexts these attributes and assumptions become written in to cultural organizational norms. The contemporary under-representation of women in senior positions still reinforces the masculine 'norm'; the woman is the exception to the masculine rule. In this way, female academics are written/positioned as the 'other' (Eveline \& Booth, 2004), located in the 'ivory basement', and structurally positioned as 
unable to have their experiences written about (Eveline \& Booth, 2004). As Bird observes, despite much research 'complex systemic barriers to women's opportunities and advancement in universities remain' (2011: 203). Existing literature has focused on women themselves, as disadvantaged in research and managerial careers (Park, 1996; Priola, 2007; Radon, 2002; Parsons \& Priola, 2013; van den Brink \& Stobbe, 2009) For Knights \& Richards (2003) masculinised discourses are at the root of sex discrimination within the academy. Pacholok (2009) points to the importance of occupational cultures reinforcing hegemonic masculinities. The dominant values within the academy: science, reason and rationality, have a cultural and political history of being not only male attributes (as taken issue with by Wollstonecraft, 1792) but ones which are re-reproduced within the academy (Benschop \& Brouns, 2003; Knights \& Richards, 2003; van den Brink \& Stobbe, 2009). Van den Brink \& Stobbe (2009) term the ways in which gender is 'done' in academia the 'paradox of visibility': women are perceived to be less employable, despite their over representation, and higher achievements at undergraduate and graduate level. Gendered structures matter (van den Brink \& Benschop, 2009) and Bird (2011) argues institutional structures erect systemic barriers which disproportionately disadvantage women. As masculinity, rationality and bureaucracy are historically intertwined (Pullen, 2006, p278), the combination of gendered scientific assumptions (Wacjman, 1991; Longhino, 2010) and bureaucratic operating procedures, in male dominated contexts, translate into working cultural 'norms'. This understanding enables us to make sense of the ways in which women are disadvantaged; this is not only disproportionate, but nuanced and multiple. Rendering this explicit opens a space to challenge. As Parsons \& Priola observe 'the politics of daily resistance has significant potential for change, at least at the institutional or organizational level' (2013, p581). 


\section{Methodology and auto/biographies as method}

The empirical focus of this research is on women academics, and more specifically the way in which gender is performed upon women where cultural practices write masculinity as the 'norm', so cultural sexism becomes normalized and ordinary

To reflect on this process this article adopts, perhaps unsurprisingly, a feminist epistemology. Set in debates about the masculinised status of science and the knowledge that is derived in that intellectual paradigm, we are reminded by Code (2000) that the way in which we access and construct knowledge has consequences in terms of our capacity to challenge or reinforce existing power relationships (see also Doucet \& Mauthner, 2007).

Methodologically, auto/biography is a method associated with feminist and feminine writing. Most auto/biography has been and is concerned with 'great lives' however, what the feminist method does is give expression to everyday lives, to the ordinariness of experience (Stanley, 1992). The empirics in this research are premised on lived experiences, biographical interviews and 'personal narratives'; these are used qualitatively to provide a cultural analysis which considers the way which myths and cultural norms are embodied (Reinharz, 1992 p129). Methodologically, this reminds us of the intersubjectivity of the relationship between the researcher and the researched. The writing of women's' biographical, oral history, is 'a circular process: the woman doing the study learns about herself as well as about the woman she is studying' (Reinharz, 1992, p127). 
I came to this research through my own experiencesiii. But it was only in talking to other women, in hearing their experiences, in reading and then writing about this, that I was able to make sense of what had happened to me. At first, it seemed I had been positioned as powerless, yet through talking with other women, and through my own writing on this topic, I have come to recognise my autonomy. As an undergraduate for some, my good marks were attributed not to my ability, but because I was sleeping with one of the staff (I was not). I thought it was just me this was happening to. As a postgraduate attending a conference early on in my $\mathrm{PhD}$, I was invited back to the room of a male academic within the profession when I declined, 'come on' he said, 'that's what you've come here for isn't it?' I thought it was just me. As a permanent member of staff, after a conversation where the absence of women in senior positions was concluded by a male professor explaining to me, 'you see the thing you don't understand dear, is that women just don't do your discipline'. By the time this sentence was spoken to me, I had spent several years speaking with, and discussing with other women their experiences. My reading and empirical research had enabled me to understand, that it was not just me (and that last expression of ignorance from a senior male professor just made me cross and more determined to write this article). As I listened to other women talk about their experiences, I began to reflect on the need to write about this as a means to challenge this regulation (cf. Höpfl, 2000). Included in this are systematically collated 6 years worth of conversations with female colleagues about their experiences of the sector within which we work. My delay in writing this up as an article has been a reflection, not only on the experiences of my colleagues, but an awareness of my position of privilege in relation to women across British society more generally, and indeed globally. As a male colleague said to me, who wants to listen to a load of middle class women whinging? And I realise the effect that this had on stalling my own 
writing on this issue. I lost confidence in what I was doing. Maybe he was right? I shelved the writing, and yet as women who had given their stories asked what had happened to the paper, again I realised that I had become subject to the very discourses that I had set out to challenge. What I learned (Reinharz, 1992, p127) was that I was being positioned by individuals within dominant power structures (which were masculinised discourses); this was the writing of my own regulation (cf. Höpfl, 2000). To challenge this we also need to explore ways in which feminine writing might play a role in re-writing the 'rules of the game'.

The auto/biographies used in this article reflect women's voices and the way in which they have been written as female subjects, having gender 'done' or written on to them by masculinist discourses. They also reflect a desire to reject this positioning. I therefore subsequently explore the role of feminine writing in disrupting the ways in which gender in the academy may be 'performed' (cf. Butler, 1999; Pullen, 2008).

In doing this research, I spoke with women from across the spectrum of science, arts, humanities and social science. Those voices who are written here are across faculty position (from PhD to Professor) and include all tiers of current universities in the UK (e.g. Russell Group, 1994 Group, Post 1992). I gained access to these women through a self selecting sample, a snowballing of discussions and conversations, at departmental seminars, at conferences, women told me their own stories and encouraged other women to contact me to share theirs. I had in depth interviews with some women, anecdotes and email exchanges from many others. One of the interesting things that I noticed was that every time I presented on this topic, I would see women around the room nod in recognition. Clearly, 
there may be some women who do not wish to engage in this kind of analysis, nor conversation. But I have been consistently struck by the shared experience and recognition of women, whether willing to have their stories overtly used or not. (Approximately half of the women who described their experiences to me, asked that these not be used for fear that in some way, however small, there may be repercussions. (More on which below). These stories have been collected over a time period of approximately 6 years, and the empirics within this article are anonymised excerpts from just some of those stories.

\section{Writing to Expose: Leaky pipelines}

For some, the under-representation of women at senior level is a result of a 'leaky pipeline' and the issue is often framed around childcare. A recent article in Nature concluded 'childcare is one major factor that blocks the career of many women' (Editorial, 2013: 5) as women leave to have children, or take time out for childcare which impacts upon their capacity to climb the ranks. This starting point positions childcare as a women's issue, rather than a parental one. By sleight of discourse, it deftly absolves organizations of responsibility putting the emphasis on the women themselves, rather than the need to amend institutional structures to support parents and reinforcing the hegemonic masculine norm where women are positioned as child careers as well as child bearers. Consider this example from an early career academic: On a temporary contract, Angela described how her head of department had told her she had to make a choice between children and an academic career, making it clear that if she was choosing children, she would have no career in her current institution. On returning from maternity leave Miranda was told you'll have to pull yourself together, you're letting the team down (postdoctoral researcher) on discussion of her medical note detailing her post-natal depression. On announcing her pregnancy to 
her head of department Linda was advised that she will need to find cover for the teaching headache that you are going to be leaving us with (junior academic). While Nature may be right to highlight that childcare may provide one mechanism through which women are currently structurally disadvantaged we need to problematise and reflect upon the way in which cultural norms write these structural assumptions into daily practice.

\section{Fear (and loathing of women in the academy)}

Fear was an over-riding feature of these women's stories and it was articulated in the concern not that the story would be told, but that the women themselves would be identifiable, and repercussions would follow for 'speaking up'; these were both implied and overt. Ahmed (2004) highlights how fear is an important component in cultural positioning and this featured heavily in my data. One woman told how she had been directly told 'if you say anything about this [her complaint of sexism another colleague was being subjected to] I will make sure your career here is finished (junior career researcher). Indirectly the effects were just as pernicious: I can't believe I am telling you this, and please don't use this [experience I have had] as my colleagues may guess who I am. I can just about manage to negotiate my way within the department at the moment, but if I was thought to be complaining then God, my life would just become unbearable (mid-level academic). Other women reflected on their reticence to speak up about their experiences as they perceived that this would be come back negatively on them, when it came to promotions or pay progression issues, or indeed just the general experience of daily working life. I just know that if I bring this up I will be presented as a problem to other colleagues. I did complain once about being bullied by a senior manager. HR brought the manager and myself face to face 
and asked him if he had bullied me. The consequences of that, as I am sure you can imagine, were horrendous for the ways in which XXX continued to behave towards me. And it didn't end with him, I was constructed as mentally unstable, unable to do my job properly, this was a rumour that went round the department (early career researcher). Of course this kind of construction of a junior female, by a senior male, in the context of a sector where the masculine is the norm, also has the danger of becoming a self fulfilling prophecy. This expression of fear provides a backdrop though which cultural sexism can become enacted, embedded and written in to daily practice, for if we are afraid to speak out, how can we challenge?

\section{Cultural sexism}

The argument here is that these experiences are symptomatic of wider masculinised hegemonic discourses and a resurgence and revisiting of academic literature to concerns with sexism which has been termed 'retro-sexism' (Williamson, 2003), enlightened sexism (Douglas, 2013) or 'critical sexism' (Ahmed). It is the regularity and ordinariness of gendered positioning which comes to constitute what is termed 'cultural sexism' (Savigny, 2014). The phrase 'cultural sexism' combines the notion that sexism is an everyday, ordinary, occurrence, combined with the cultural context which gives rise to it, and its cumulative, drip drip effects that have impacts and outcomes on women, and which may disempower or marginalize their experiences and contributions. This is instantiated through routinised, daily cultural practices. In Butler's terminology, 'performativity is not a singular act, but a repetition and a ritual, which achieves its effects through its naturalization in the context of a body, understood, in part, as a culturally sustained, temporal duration' (Butler, 
1999: xv). Gendered is performed in cultural sexism through its repetition, its ritualisation, and in this case by its discursive and cultural manifestation on women's academic 'performance'. Here the body is regulated through writing (cf Höpfl, 2000). Butler's formation of Foucauldian questions encourages a reflection on the productive capacity of power where 'regulative strategies produce the subjects they come to subjugate' (Butler, 1999: 125). Yet this structural positioning of agents as outcomes of regulative structures perhaps denies, or at least downplays, possibilities of challenge, renegotiation, and change.

\section{The ordinariness of 'cultural sexism'}

The writing of women's experiences thus far has been one through which cultural sexism is 'ordinary', but how does sexism become so ordinary? Existing research has sought to uncover and quantify the ways in which there is an 'unconscious gender bias' against women (Editorial, 2013:5) in apparently 'gender neutral' recruitment and selection (van den Brink \& Benschop, 2012) and promotion processes (Bird, 2011). Women fare better in gender blind evaluations of their CVs (Goldin \& Rouse, 2000) and worse when gender is known (Moss-Racusin et al, 2012). Qualitatively, an eminent professor observed, I have sat on promotions committees where I am the only woman in the room. Women's CVs are routinely picked through, the gaps emphasised, the weaknesses 'exposed'. Indeed, in one meeting a woman's CV was seen as particularly weak as although she had a wide range of interdisciplinary publications, and an outstanding REF return, they were still deemed insufficient quality for promotion. After the committee I went and check the committee chair's publications. He was in the same journals! But what can you say without repercussions? I watch male candidates sail through, sometimes with lesser publications than their female counterparts. One regular justification is that 'well he might not be quite 
ready, but we had better promote him as he will leave'. In all my years on a committee have never seen or heard of a woman being promoted on this basis. While men are judged positively on their potential, women seem to be judged negatively on their omissions'.

Underlying this research is the implication that women face a 'chilly climate' within academia (Hall \& Sandler, 1982). There is a cumulative, drip drip, of routinised practices and discourses where women are marginalised, their contributions ignored or devalued, their role assumed to be that of inexperience which can result in their loss of confidence. On the opening of a major research conference, I watched a senior male say to new female member of staff, can you get some coffees for those (male) guests? Oh, you are about to speak, sorry I thought you were a secretary (PhD student). Not only is this demeaning to secretaries, the assumption that their function within the organisation is somehow beneath that of the academic, rather than different, but this also contained the assumption that a young woman was clearly not capable of opening a conference, nor having a research contribution to make in her own right. It is this daily marginalisation I presented my thought out projections for improving the research profile in the department. This was dismissed until later in the meeting a male colleague presented my idea, and it was greeted with enthusiasm and acceptance (mid career academic). Being the 'invisible woman' in the room again is part of the cumulative experience. Another mechanism which devalues and belittles women's work contribution is the focus on their sexuality - meetings are quite regularly addressed to my chest (early career researcher) - where women's gender is performed in terms of their actual or expected sexual attractiveness. I wear quite colourful make up and clothing, why should I change my style to fit the expectations of the (grey) men around me, yet my contribution to meetings appears to be relegated to my looks, my 
appearance, my appearance not my intellectual contributions seem to be the basis of comments and responses to me (mid career academic).

Sexualisation of their professional experience is one way in which women are excluded from the masculinised discursive professional context. Gender constructions are written and performed beyond the meeting room and corridors of the academy. Despite my best efforts, after a couple of years in a department I realised that the key decisions were being made on the golf course, over beers after a game of football (early career researcher). The old boys' network is repeatedly attributed to the masculinist written exclusion of women from key decisions, mentoring opportunities, and promotions considerations

\section{Writing to challenge: Re-writing structures \& cultures}

As I spoke to women, not only did we discuss their experiences, but this also raised the question, what can we do? Within the literature there have been excellent accounts of effective leadership and mentoring schemes (Eveline \& Booth, 2004) and workshops aimed identifying and tackling gendered barriers to women's advancement within institutions (Bird, 2011) and within disciplines (for example 'Society for Women in Philosophy' [http://swipuk.org/]). Robin Morgan (1970) noted that 'Sisterhood is powerful' and the collective support engendered in sharing practices and techniques of resistance has been shown to provide women with strength to continue (as noted by some of my women contributors; see also Parsons \& Priola, 2013). It is not possible here to exhaust the plethora of available options, but the intention below is to reflect on the ways in which the rules of the game are 'written', and how this might be challenged. In critical and feminist 
debates, resistant readings, and re-writing of texts is a mechanism of empowerment (see Cranny-Francis, 2003, p114-28). Feminine re-writing in this article is a mechanism and a process by which hegemonic masculine cultural and structural norms can be challenged and, disrupted (cf. Pullen, 2008). Re-writing may use the written word, but it can also be verbal, it can be based in ideas and in material conditions. What follows are just two examples: one structural, one cultural, of ways in which we may think about feminine re-writing of the 'rules of the game', in our structural and cultural contexts.

\section{Challenging ordinary cultural sexism: the re-writing of masculine meritocracy in organizational structures}

As noted above, feminist epistemologies provide us with the tools to reflect on challenges to existing behavior, practices and processes. Organisational structures have both internal and external components; internal rules and standard operating procedures, are intimately to external national legislation. Gender mainstreaming has become an important legislative strategy at national and international level (Bendl \& Schmidt, 2013; for nuanced discussion see Eveline, Bacchi \& Binns 2009). Legislation does not exist in a vacuum, but rather within a gendered regulatory system which can limit its effectiveness (Eveline \& Todd, 2008). I reflect on the way in which seemingly gender neutral structures are replete with gendered assumptions and regulatory practices with an analysis of the recent re-writing of Britain's equal opportunities legislation.

In 2011 equal opportunities legislation was amended to read as follows:

The new positive action provisions mean that it is not unlawful to recruit or promote a candidate who is of 
equal merit (emphasis added) to another candidate, if the employer reasonably thinks the candidate:

-has a protected characteristic that is underrepresented in the workforce; or

- That people with that characteristic suffer a disadvantage connected to that characteristic.

However, positive action does not allow an employer to appoint a less suitable candidate (original emphasis) just because that candidate has a protected characteristic that is under-represented or disadvantaged.

(Government Equalities Office, 2011)

This legislation states that where candidates are of equal merit, and are under-represented in the workforce, then positive action should be used to employ those who have been previously structurally disadvantaged. As Nancy Fraser (1985) has observed, gender blindness does not equate to gender neutrality. Feminine writing as an approach encourages us to reflect upon the way in which the problem lies in the way in which the rules themselves are written. The above legislation redefines equality of opportunity, at interview, as based on merit. The key point however, is who is defining what 'equal merit' means? At present, what 'equal merit' means is determined according to existing discursive regimes which have an inbuilt bias towards the status quo. This inherent conservatism thus entails a reproduction of existing gendered biases and asymmetries (see Rip, 1997:33; Bird, 2011). As Littler (2014) observes the ideology of meritocracy has become a means through which plutocracy is reinforced by stealth. Merit is something which is also presented as a gender neutral category, where the same options are available to all candidates. Yet as van den Brink and Benshop (2012) show, assuming that selection and recruitment process are gender neutral, means that systemic gender biases are rendered invisible; the woman herself is positioned as responsible for the outcome, or, for the choices she makes. This 
assumption of gender neutrality thus obscures the systemic bias which militates against women (van den Brink \& Benschop, 2012 p84; Benschop \& Doorewaard, 1998). For Benschop and Browns, this means that the 'quality' issue is thus framed as a women's problem rather than a problem for organizations (2003:203). If we want to talk about what constitutes 'equal merit' in an organizational environment, rather than embedding conservative norms and the inequalities embodied within the status quo, it might be useful to rethink the question and to recognize that the term 'equal merit' is situated in gendered structures; so what assumptions and consequences are contained in the current masculinist writing of those structures?

In the above legislation, the masculinist writing of the term 'merit' means that the structurally disadvantaged remain structurally disadvantaged and this takes place, primarily, in two ways. First, as suggested above, the way in which merit is defined in the first instance is at stake, and it is this definition which may prevent candidates who do not perform according to the standards of hegemonic masculinity from reaching the shortlist in the first instance (where leadership discourses are located in masculine regulatory structures of rationality [Sinclair, 2007] ). In the early stages of writing this article Jo Johnson (London Mayor Boris Johnson's brother) was appointed to UK PM David Cameron's advisory team as the head of the Policy Unit. As the Today programme announced his appointment he was defined as 'educated at Eton and Oxford' (25/4/13), conforming to the white middle class male stereotype which characterises the contemporary government. I did find myself wondering whether out of all the people in the country, just what it was about this white middle class connected male that made him the most suitable for post. And just how were those characteristics reflected in the job description? It is not only his 
characteristics that make him the best person for the job, but the way the job is conceived of and written in the first place which enables him to be the 'best', 'most suitable' candidate. The point here being, as with contemporary politics, when we talk within institutions about merit or what is meritorious, when we discursively construct what 'good enough' looks like, not only does this become something which seems to contain the characteristics of white, middle class, able bodied, heterosexual men, but it is also something which is often defined and written by dominant hegemonic discourses; reinforcing rather than challenging them.

Second, once the rules are written, candidates whose interests are not reflected in this definition face a further problem. Even if candidates can compete and make it to the shortlist, which given the way in which they are structurally disadvantaged means that their achievement becomes greater than that of their counterparts even if they are 'equal' on paper, discrimination can still occur through the category of 'suitability'. For who defines whether a candidate is more or less suitable? Answer: the selection panel. But selection panels tend to choose in their own likeness, and as noted above, that female candidates are often judged more harshly than men. Therefore, if we really wish to tackle the structural disadvantaging of women (and this argument is extendable to ethnic minorities, and those who are not located in the middle classes), then we need selection panels and selection criteria which reflect this. If the primary aim of the selection criteria was to select a candidate who would advance the interests of previously structurally disadvantaged groups' (this structural disadvantaging which forms around class, ethnicity, gender, sexuality, religion) the question is thus raised - would the 'equal merit' desired by the new legislation look the same? While this question is thus posed at national legislative level, organisational 
interpretation also is important. Within the institution the question thus hinges around who is defining what it means to be 'good enough' for promotion or for the job? And does this challenge or reinforce hegemonic masculine power structures?

As has been noted, hegemonic masculinist discourses have been successful in preventing women from achieving leadership positions as their circulation and negotiation serve to reinforce autonomous, masculine, white male norms as properties of leadership (Amey \& Twombly, 1992; Amey \& Eddy, 2002; Eddy \& VanDerLinden, 2006; Ford, 2006; Sinclair, 2007). Thus it is in the definition, the writing of the rules where we see dominant interests embedded. This exposure provides the basis for challenge and disruption, in this case through feminine re-writing.

\section{Challenging ordinary cultural sexism: Re-writing masculine cultures}

Not all of us have the opportunity however, to be in a position where we are writing rules Feminine writing reminds us of our autonomy and capacity to challenge dominant cultural norms. Re-writing cultural statements and assumptions is a powerful mechanism for change (cf. Parsons \& Priola, 2013). But how can feminine writing challenge dominant masculine norms? One very simple mechanism is a straightforward critique of the way in which we as colleagues engage with each other and with our organisational context; looking to the agents within that context provides a site where rewriting of experience may take place. In literature on humour, we are invited to reflect on the way in which racist jokes are contingent upon race: once the race element is reversed or re-written, the 'joke' doesn't work, the racist component is exposed (cf. deSousa, 1987). And so with sexism, if we re- 
write statements made about and towards women, if they don't work with men, then we are exposing and challenging their sexism as well as providing a space to re-write and rethink how gender is being 'done' (West \& Zimmerman, 1987). Simply put, this requires that we when we hear a statement we may feel is problematic - we ask the question would this work the other way round? Reversing, or re-writing statements is one way in which hegemonic masculinist assumptions and cultures can be thoughtfully challenged. As Parsons \& Priola demonstrate, 'targeting normalizing discourses both formally...and informally...[has been] widely used as an attempt to make interventions into accepted gender norms and their associated power structures' (2013, p594). In practice, we then find ourselves in the position where we might question: would we ever remark in surprise that 'we had a male Vice Chancellor once'. Would we ever ask 'can you be on our selection panel as we need a [token] man?' Would it be said to a man 'you need to make a choice between children and a career in research'. Would it be said about a man 'He only got that job because he was sleeping with her'; 'he won't make professor as he has children'? These examples reverse the statements of female academics with whom I spoke). Reversing gender assumptions in seemingly 'innocuous' statements enables us to challenge masculinist norms: if we feel uncomfortable, or it feels strange to make these statements about men, then should it not feel strange or uncomfortable to make these statements about women.

\section{Conclusion}

The aim of this paper has been to engage in feminine writing: to restore the 'woman' academic as active through the writing of her voice and the way in which she experiences 
academia and as a mechanism through which to disrupt hegemonic masculinist norms. In this writing I have sought to expose the power structures which position women through the performance of gender within academia. I have sought to reflect a dualism: women as recipients of gender being 'done' to them in organizations; but to argue that this contains the basis of women's agency, they can also be empowered drivers of change. Women's history of existence in the academy provides a story of advancement, progress and struggle. That struggle is written into different forms in different cultural and structural contexts. Much has been achieved, and we stand on the shoulders of our sisters who went before us. There is still work to do, however, and feminine writing and re-writing women in academia provides a space where hegemonic masculinist discourses can continue to be exposed, challenged and changed. The writing of women's experience opens up space where we may interact as agents and disrupt hegemonic masculine organisational cultures and structures. This article has used the writing of women's experiences, which are situated within a culture whereby 'sexism is ordinary', as means to render power structure visible, so that we may 'reverse and rewrite' the cultural and structural rules of the game. 


\section{Bibliography}

Acker, J (1990) 'Hierarchies, jobs, bodies: a theory of gendered organisations' Gender and Society 4 (2) pp139-58

Acker, J (2006) 'Inequality Regimes. Gender, class and race in organisations' Gender \& Society 20 (4) pp441-64

Ahmed, S (2012) The cultural politics of emotion (New York: Routledge)

Ahmed, S (2014) 'Making Feminist Points' Woman Theory http://womantheory.wordpress.com/2014/02/06/making-feminist-points-by-sara-ahmed/

Allen, E (2011) Women's Status in Higher Education ASHE Higher Education Report: Volume 37 Number 1 (San Francisco: Wiley Periodicals)

Amey, M. J. \& Eddy, P. L. (2002) 'Leadership' in A. M. Martinez Aleman \& K. A. Renn (eds) Women in Higher Education (Santa Barbara, CA: ABC: CLIO) pp482-6

Amey, M. J. \& Twombly, S. B. (1992) 'Revisioning leadership in community colleges' Review of Higher Education 15 (2) pp125-50

Bannerji, H., Carty, L., Dheli, K., Heald, S \& K. McKenna (1991) Unsettling Relations (Toronto: The Women's Press Collective)

Beckwith, K (1997) 'A common language of gender' Politics \& Gender 1 (1) pp128-37

Bendl, R \& Schmidt, A (2013) 'Gender Mainstreaming: An Assessment of Its Conceptual Value for Gender Equality’ Gender, Work \& Organization 20 (4) pp364-81

Benschop, Y \& Brouns M (2003) 'Crumbling Ivory Towers: Academic Organizing and its gender effects' Gender, Work \& Organisation 10 (2) pp194-211

Benschop, Y \& Doorewaard, H (1998) 'Covered by equality: the gender subtext of organizations' Organization Studies 19 (5) pp787-805

Bird, S. R (2011) 'Unsettling Universities' Incongruous, Gendered Bureaucratic Structures: A Case Study Approach' Gender, Work and Organization 18 (2) pp202-30

van den Brink, M \& Benschop, Y (2012) 'Slaying the seven-headed dragon: The quest for gender change in academia' Gender, Work \& Organisation 19 (1) pp71-92

van den Brink \& Stobbe, L (2009) 'Doing Gender in Academic Education: The Paradox of Visibility' Gender, Work \& Organization 16 (4) pp451-70

Browne K (2004) 'Genderism and the bathroom problem: (Re)materialising sexed sites,(re)creating sexed bodies'. Gender, Place \& Culture 11(3): 331-346.

Butler, J (1999/ 1990) Gender Trouble (New York \& London: Routledge)

Connell, R (2009) Gender (Cambridge: Polity) 
Counting Women In (2013) Sex and Power in Britain http://www.countingwomenin.org/wpcontent/uploads/2013/02/Sex-and-Power-2013-FINALv2.-pdf.pdf

Code, L (2000) 'Epistemology' in eds. A. M. Jaggar \& I. M. Young (2000) A Companion to Feminist Philosophy (Oxford: Blackwell)

Cranny-Francis, A., Waring, W., Stavropoulos, P. \& J. Kirby (2003) Gender Studies. Terms and Debates (Basingstoke: Palgrave)

de Sousa, R. (1987). When is it wrong to laugh? In J. Moreall (Ed.), The philosophy of laughter and humor (pp. 226-249). Albany, NY: State University of New York.

Doucet, A. and Mauthner, N. (2007) 'Feminist methodologies and epistemologies' in C. D. Bryant \& D. L. Peck (editors) The Handbook of 21st Century Sociology (Thousand Oaks, CA: Sage)

Douglas, S (2010) The Rise of enlightened sexism. How pop culture took us from girl power to girls gone wild (New York: St. Martin's Griffin)

Eddy, P. L. \& VanDerLinden, K. E. (2006) 'Emerging definitions of leadership in higher education. New visions of leadership or the same old 'hero' leader'? Community College Review 34 (1) pp5-26

Editorial (2013) 'Science for all' Nature $7^{\text {th }}$ March vol 495 p5

Eveline, J \& Booth, M (2004) " "Don't write about it": Writing "the other" for the ivory basement' Journal of Organizational Change Management 17 (3) pp.243-55

Eveline, J, Bacchi, C \& J. Binns 'Gender Mainstreaming versus Diversity Mainstreaming: Methodology as Emancipatory Politics' Gender, Work \& Organization 16 (2) pp198-215

Ford, J. (2006) 'Discourses of Leadership Leadership 2 (1) pp77-99

Gerhardi, S (1994) 'The gender we think, the gender we do in our everyday organizational lives' Human Relations 47 (6) pp591-610

Goldin, C \& Rouse, C (2000) 'Orchestrating Impartiality: The Impact of 'blind' auditions on female musicians' The American Economic Review90 (4) pp715-41

Grey, C \& Sinclair A (2006) 'Writing Differently' Organization 13 (3) pp443-53

Hall, R \& Sandler, B (1982) The classroom climate a chilly one for women (Washington, DC. Project on the status and education of women. Association of American Colleges)

Hall Jamieson, K (1995) Beyond the Double Bind: Women and Leadership (New York: Oxford University Press)

Higher education Statistics Agency (HESA)(2012) 'Statistical first releases' http://www.hesa.ac.uk/content/view/2077/239/ 
Höpfl, H (2000) 'The Suffering Mother and the Miserable Son: Organizing Women and Organizing Women's Writing' Gender, Work \& Organization 7 (2) pp98-105

Hunter, R (2010) 'An account of feminist judging' in eds R. Hunter, C. McGlyn \& E. Rackley Feminist Judgments. From Theory to Practice (Oxford and Portland, Oregon: Hart Publishing Ltd)

Kennedy, H (1995) 'Prisoners of Gender' Times Higher Education Supplement $6^{\text {th }}$ November http://www.timeshighereducation.co.uk/95835.article

Knights, D \& Richards, W (2003) 'Sex Discrimination in UK Academia' Gender, Work \& Organisation 10 (2) pp213-38

Littler, J (2014) 'Meritocracy As Plutocracy: The Marketising Of 'Equality' Under Neoliberalism' New Formations 80-81 pp52-72

Morgan, R (1970) Sisterhood is Powerful (New York: Vintage Books)

Moss-Racusina, C., Dovidiob, J. F., Brescollc, V. L. Grahama, M.J. \& J. Handelsman (2012) 'Science faculty's subtle gender biases favor male students' Proceedings of the National Academy of Sciences of the United States of America109 (41) pp16474-9

Murray, R (2012) 'Quotas for Men' American Political Science Association Meetings, New Orleans, August

Pacholok, S (2009) 'Gendered Strategies of Self: Navigating Hierarchy and Contesting Masculinities' Gender, Work and Organization 16 (4) pp473-500

Parsons, E \& Priola, V (2013) 'Agents for Change and Changed Agents: The micro-politics of Change and Feminism in the Academy' Gender, Work \& Organization 20 (5) pp580-97

Park, S.M. (1996) 'Research, teaching and service: why shouldn't women's work count?' Journal of Higher Education 67 (1) pp46-84

Parsons, E \& Priola, V (2013) 'Agents for Change and Changed Agents: The micro-politics of change ad feminism in the Academy' Gender, Work \& Organization 20 (5) pp580-97

Priola, V (2007) Being female doing gender: Narratives of women in education management' Gender and Education 19 (1) pp21-40

Pullen, A (2006) 'Gendering the Research Self: Social Practice and Corporeal Multiplicity in the Writing of Organizational Research' Gender, Work \& Organization 13 (3) pp277-98

Pullen, A \& Rhodes, C (2008) 'Dirty Writing' Culture and Organization 14 (3) pp241-59

Raddon, A (2002) 'Mothers in the academy: positioned and positioning within discourses of the "successful" academic and the "good mother" Studies in Higher Education 27 (4) pp387403

Reinharz, S (1992) Feminist Methods in Social Research (New York: Oxford University Press) 
Rhodes, C \& Brown A. (2005) 'Writing Responsibly: Narrative Fiction and Organization Structures' Organization 12 (4) pp467-91

Rich. A ( 1979/1986) On Lies, Secrets and Silence (London: Virago)

Rip, A (1997) 'Higher forms of nonsense' in NWO The future of the peer review system. The Hague: Netherlands Organization for Scientific Research (NWO)

Savigny, H (2014) 'Women, know your limits: Cultural sexism in academia' Gender and Education 26 (7) pp794-809

Sinclair, A (2007) Leadership for the Disillusioned (Sydney: Allen \& Unwin)

Spender, D (1982) Women of Ideas (London: Routledge \& Kegan Paul)

Stanley, L (1992) The Auto/biographical I. The theory and practice of feminist auto/biography (Manchester: Manchester University Press)

Sword, H (2012) Stylish Academic Writing (Cambridge, MA: Harvard University Press)

Wacjman, J (1991) Feminism Confronts Technology (Oxford: Blackwell)

West, C \& Zimmerman, D (1987) 'Doing gender' Gender and Society 1 (2) pp125-51

Williamson, J (2003) 'Retrosexism' Eye Summer 12 (48) p44

Wollstonecraft, M (1792/2004) A Vindication of the Rights of Woman (London: Penguin)

Woolf, V (1928/2008) A Room of One's Own (Oxford: Oxford University Press)

\footnotetext{
i I am not seeking to essentialise the differences between men and women. Indeed a female senior lecturer was not alone in noting how the senior female professors can be just as bad. I have seen quite a few of them behave as badly as the men. I know I shouldn't criticize them but it is a really depressing thought, do women have to behave in this masculine way if they really want to get to the 'top' of the profession? And indeed there is a literature which discusses the ways in which women come to adopt masculine behaviours when working in male dominated organizations (Benschop \& Doorewaard, 1998; Hall Jamieson, 1995; van den Brink \& Stobbe, 2009) $)^{\mathrm{ii}}$.
}

\footnotetext{
ii I do recognize that it may seem a little inconsistent to talk about disrupting categories and then use the term 'women'. However, following Kath Browne 'While I wish to contest the boundaries of gender and sex, I also seek to be intelligible' (2004: 443) and so while the category of woman is acknowledged as fluid, at the same time the term is applied here in order to render the experiences accessible and visible. With thanks to Nicki Smith for this point.
} 